\title{
Fighting against Impunity in Ethiopia: An Emphasis on Crime against Humanity
}

\author{
Dersolegn Yeneabat \\ School of Law, Arba Minch University, Arba Minch, Ethiopia \\ Email:derso2012@yahoo.com
}

How to cite this paper: Yeneabat, D. (2020). Fighting against Impunity in Ethiopia: An Emphasis on Crime against $\mathrm{Hu}$ manity. Beijing Law Review, 11, 43-63. https://doi.org/10.4236/blr.2020.111004

Received: November 5, 2019

Accepted: January 7, 2020

Published: January 10, 2020

Copyright $\odot 2020$ by author(s) and Scientific Research Publishing Inc. This work is licensed under the Creative Commons Attribution International License (CC BY 4.0).

http://creativecommons.org/licenses/by/4.0/

\begin{abstract}
There are different reports and literatures that display crime against humanity which is one of the international crimes has been committed in Ethiopia for the last couple of decades. The main emphasis of this paper is to assess whether is it possible to convict those who found guilty (if any) by using the current Ethiopian legal frameworks with a view to fight against impunity as the government of Ethiopia has an erga omnes duty. For this purpose, clear evaluation is made on the former penal code, FDRE constitution and FDRE criminal code as to how a crime against humanity is criminalized. Accordingly, the paper argues that the former Ethiopian penal law stipulated crime against humanity only as a title which is blurred with the crime of genocide in a given provision. Similarly, it is not certain and clear that the FDRE constitution gives a full picture of crime against humanity which is basically divorced from the criminal principle of legality. Though the FDRE criminal code was expected to give much recognition in a way that enables the government to prosecute those who committed a crime against humanity, paradoxically it completely failed to give at least certain recognition. Therefore, using these laws to prosecute those who found guilty in committing a crime against humanity has different implications. Firstly, it will help real criminals to escape from criminal punishment. Secondly, it contradicts with the principle of legality which is one of the vital criminal law principles. Lastly, it will serve as a weapon for the violation of fundamental human rights of citizens by the government.
\end{abstract}

\section{Keywords}

Crime against Humanity, International Core Crimes, Erga Omens Duties, Jus Cogens Norms, Ethiopian Legal Framework

\section{Introduction}

Crime against humanity is among the core International crimes which attained 
the jus cogens ${ }^{1}$ status. However, unlike genocide and war crimes, there is no precise convention at the international level and thus its definitions are envisaged in different legal instruments. Nevertheless, the international community notwithstanding some contentious issues has reached on unanimity that such core crimes which include war crime, a crime against humanity, genocide, and aggression should be prosecuted. Any state around the world has erga omnes duties to have both legal and institutional frameworks that would enable it to fight against impunity with regard to those core crimes.

There are different Human right organizations activists that allege the Ethiopian government for committing a crime against humanity. The Agnuak case in Gambela is one of the landmark cases that the government of Ethiopia is alleged. For instance, Human rights watch "Since late 2003, the Ethiopian National Defense Force (ENDF) has committed numerous human rights violations against Anuak communities in the Gambella region of southwestern Ethiopia that may amount to crimes against humanity". (Human Rights Watch Report, 2005). The same allegations are also invoked against the government particularly following the 2005 e.c national election. However, this particular allegation doesn't hold water on the government side. In fact, the purpose of this paper is not to prove whether the allegations were/are true or not. The fundamental purpose is rather to evaluate the possibility of fighting against impunity with regard to a crime against humanity in Ethiopia as it has an erga omnes duty to prosecute the perpetrators of such jus cogens crimes in general and against humanity in particular.

Accordingly, in this paper, the writer evaluates the extent to which crime against humanity is incorporated under the Ethiopian legal framework. Specifically, the paper tries to answer the questions; how the 1957 penal code, the Federal Democratic Republic constitution (hereinafter FDRE constitution) and the Federal Democratic Republic of Ethiopia Criminal Code (hereinafter FDRE criminal Code) incorporate crime against humanity? Is the criminalization of Crime against humanity under the Ethiopian laws compatible with the criminal principle of legality? Is there any particular feature in the Ethiopian legal regime from the international jurisprudence in enshrining crime against humanity? Are the Ethiopian laws becoming developed through time as the international jurisprudence is getting well founded regarding crime against humanity? Whether is it quite possible to fight against impunity for crime against humanity by using the current national legal frameworks?

With a view to answer the above research questions; basically doctrinal legal research (legislation analysis) method is employed. This is because of the reason that doctrinal (or "black letter") methodology refers to a way of conducting research which is usually thought of as "typical legal research". A doctrinal approach to research will focus on case-law, statutes and other legal sources. Ac-

${ }^{1}$ Jus cogens is formally defined by the Vienna Convention on the Law of Treaties as a body of "peremptory norm[s] of general international law... from which no derogation is permitted" (art 53 Vienna Convention on the Law of Treaties, 23 May 1969). Jus cogens crimes impose duties on all states notwithstanding their ratification of relevant treaty laws. 
cordingly, under this method, the former Ethiopian Penal Code, the constitution and FDRE criminal code are navigated for the purpose of answering the aforementioned questions as these laws are the essential ones regarding crime against humanity.

Regarding content, this paper essentially comprises three sections including introduction, general overview of crime against humanity and the last one is the analysis part which shows the possibility or other wise of effectively fighting impunity in Ethiopia with regard to crime against humanity. Then the paper will end up with concluding remarks.

\section{The Notion of Crime against Humanity: An Overview}

\subsection{The Evolution of the Concept of Crime against Humanity}

Historically, the term crime against humanity had been used during the epoch of French revolution when the revolutionary Maximilian Robespierre described that King Louis XVI committed "Criminelenversl' humanite" that referred crime against humanity. However, the concept was formally introduced after the conclusion of the horrific incidence of the WW II in the Nuremberg charter (Alemayhu, 2010).

The draft of Hague Conventions on the laws and customs of War on land in 1907 by Martens later called "Martens clause" described crime against humanity as part of the international law. Nonetheless, the notion of crime against humanity was just used after World War I on 28 may, 1915, upon Russia, France, Great Britain, and USA (allied powers) commend the malevolent act of the ottoman Turkey against the Armenians as crime against civilization and humanity (Cassese, 2003). The agreement between USA, UK, USSR and France called London agreement which was held after WW II that gives apposite acknowledgment about crime against humanity under article 6(c). This provision stated that crime against humanity as it includes:

murder, extermination, enslavement, deportation, and other inhumane acts committed against any civilian population, before or during the war or persecutions on political, racial or religious ground in execution of or in connection with any crime within the jurisdiction of the tribunal, whether or not in violation of the domestic law of the country Where perpetrated (Cassese, 2003).

However, it is worth mentioning that this specific article stipulated as if crime against humanity is committed only in times of war though the subsequent developments show that crime against humanity may be committed not only in times of war but also in times of peace.

Similarly, crime against humanity was incorporated at the time of the $\mathrm{Nu}$ remberg trial. However, the trial has blurred crime against humanity and genocide together and provided little description on the constitutive rudiments of each crime (Cryer et al., 2007). Regarding crime against humanity, more crucial 
improvement has happened when the Security Council has established the two ad hoc tribunals in response to the outrageous crimes committed in former Yugoslavia and Rwanda (Cryer et al., 2007).

The first International tribunal established by the United Nation General Assembly (UNSC) in 1993 right after the fall of Berlin wall for the prosecution of those who were found responsible for the violation of international humanitarian law in Yugoslavia is known as International Criminal Tribunal for Yugoslavia (here in after referred as ICTY) (Cassese, 2003). Pursuant to article 5 of this statute, persons are responsible and prosecuted if crimes like murder, extermination, enslavement, deportation, imprisonment, torture, rape, persecutions on political, racial and religious grounds and other inhumane acts are committed in armed conflicts whether it is international or internal character and directed against any civilian population (Cryer et al., 2007). As it is apparently observed in this specific article, though, ICTY has provided crime against humanity in connection with war, it was manifested under the case of prosecutor vs Tadic the appellate chamber precluded by arguing as:

...It is now a settled rule of customary international law that crimes against humanity do not require a connection to international armed conflict... Thus, by requiring that crimes against humanity be committed in either internal or international armed conflict, the Security Council may have defined the crime in Article 5 more narrowly than necessary under customary international law (Cassese, 2003).

In ICTY to make the perpetrators of crime against humanity legally responsible to the offence they committed, identifying the intent of the offender was essential. Hence, there was a need of discriminatory intent of the offender to cause wide spread or systematic attack other than intent to destroy as in the case of genocide. In other words, the perpetrator should know the consequence of the direct attack against civilian population and also the acts committed by him/her are part of the attack or at a minimum he took responsibility that his acts were part and parcel of the attack. The perpetrators for the crime against humanity in this statute may be individuals acting in their private capacity even without sharing the goal behind the attack, by state officials acting in their private capacity, state authorities and their agent in consonant with their policy and by different entities. As indicated in the statute usually the victims are the civilians attacked on discriminatory ground in the situation of armed conflicts so long as crime against humanity is committed in armed conflict according to ICTY. According to article 7(1) of this statute a person who planned, instigated, ordered, committed or otherwise aided and abetted in the planning, preparation or execution of a crime referred to in articles 2 to 5 of the present Statute, shall be individually responsible for the crime. It was explicitly depicted in different land mark cases like Tadic and others, this statute does not require individuals to commit a crime rather they may be liable even by participating and contributing to the commission of a crime in various ways and levels provided that this par- 
ticipation must have a great connection with the crime committed. Thus, in this statute both those who commit the crime and those who give an order or instigate the criminals but do not directly and physically involved in the commission of the crime are liable. In precise words, inchoate crimes were made punishable in this statute.

International Criminal Tribunal for Rwanda (here in after called ICTR) which was established by UNSC is another crucial tribunal that contributed its part in elaborating crime against humanity in response to the atrocities in Rwanda (Handbook on International Criminal Law, 2011). According to article 3 of this statute crime against humanity is provided as "acts committed as part of a wide spread or systematic attack against any civilian population on national, political, ethnic racial or religious grounds" (Handbook on International Criminal Law, 2011). In other words, the tribunal had a jurisdiction when murder, extermination, enslavement, deportation, imprisonment, torture, rape, persecutions on political, racial and religious grounds and other inhumane acts are committed as part of a widespread or systematic attack against any civilian population on national, political, ethnic, racial or religious grounds (Handbook on International Criminal Law, 2011).

Under article 6(1) of the same Tribunal, to establish individual criminal responsibility, there must be a demonstration that;

1) The conduct for the accused contributed to the commission of an illegal act, and

2) The accused had awareness of his participation in a crime. Crimes must have been completed before the crime can give rise to criminal responsibility because article 6(1) does not criminalize inchoate offenses unlike in ICTY statute (Handbook on International Criminal Law, 2011).

In the same token, under this statute, command responsibility was applicable upon the fulfillment of the superior-subordinate relationship of the effective control between the accused and the perpetrator of the crime. This was true when the accused had knowledge about that crime was about to be committed or was being committed or had already been committed, and the failure of the accused to take measures to avert such heinous crime including the punishment of the perpetrators.

Rome statute which is entered in to force on July, 12002 , is by far and most the vital statute that gives a better jurisprudence about core crimes in general and crime against humanity in particular. Put in a wider perspective, the statute is important not only in terms of the establishment of the International Criminal Court for investigation and prosecution of international core crimes, it also signifies for the coming into existence of a new code of international criminal law (Alemayhu, 2010).

\subsection{Definition and Concept of Crime against Humanity}

As provided above the crucial international legal Instrument for discussing in- 
ternational core crimes in general and crime against humanity in particular is Rome statute. To clearly understand the definition and the concept of crime against humanity article 7 of the same statute is very important. As per this provisions crime against humanity is described crime as:

Crime against humanity means any of the following acts when committed as part of a widespread or systematic attack directed against any civilian population, with knowledge of the attack: murder, extermination, enslavement, deportation or forcible transfer of population, imprisonment or other severe deprivation of physical liberty in violation of fundamental rules of international law, torture, rape, sexual slavery, enforced prostitution, forced pregnancy, enforced sterilization, or any other form of sexual violence of comparable gravity, persecution against any identifiable group or collectivity on political, racial, national, ethnic, cultural, religious, gender as defined in paragraph 3, or other grounds that are universally recognized as impermissible under international law, in connection with any act referred to in this paragraph or any crime within the jurisdiction of the court, enforced disappearance of persons, the crime of apartheid, other inhumane acts of a similar character intentionally causing great suffering, or serious injury to body or to mental or physical health (Rome Statute of the International Criminal Court, 2002).

From the definition, the first important element is the issue of "attack". In this definition the term attack doesn't signify the military attack only. As indicated in SCSL Trial Chamber in Taylor elucidated that the concept of an "attack" is not limited to the use of armed force but may encompass any mistreatment of any civilian population. "Attack" is a concept different from that of "armed conflict" and need not be part of it. This shows that crime against humanity may also be committed in peace time also.

The other related significant concern in relation to "attack" is its character of conduct. The way that crime against humanity committed is different from that of war crimes and other crimes. According to the negotiators of ICC, the term "widespread attack" indicates the multiplicity of victims and massive attacks supported by a calculative state or organizational policy or high degree of organization and planning to commit such acts (Cerone \& Couto, 2004).

In this regard, it is good to mention what Cassese who is one of the prominent international criminal law scholar argued. He explicated that crime against humanity is different from war crime against individuals. This is because of the fact that crime against humanity is often committed in a systematic and widespread way. However, According to him, a single act may be included as crime against humanity in some situations. He further argued, "as long as there is a link with the widespread or systematic attack against a civilian population, a single act could qualify as a crime against humanity. Thus a single act, for example an act of denouncing a Jewish neighbour to the Nazi authorities-if committed against a background of widespread persecution-could amount to a crime against hu- 
manity" (Cassese, 2003).

An attack against the "civilian population" is another crucial constitutive element of crime against humanity under this Statute. The issue of putting the exact notion of "Civilian population" is dubious. The first refers, the population when the most part of it is composed of the civilians even in the presence of militaries among them does not take away their civilian status. Second, the word civilian is also interpreted to be inclusive of those no longer taking part in fighting during the moment the crimes were committed, including previous combatants who laid down an armistice and soldiers who are detained or wounded (Cryer et al., 2007).

Regarding the mental element, when the defendant committed crime against humanity, he has to be aware about the consequence and the result of his act. In other words, the acts committed are based on the knowledge of the perpetrator.

This statute embodied same list of acts like the former statutes but additionally it contains forced transfer of population, sexual slavery, enforced prostitution, forced pregnancy, enforced sterilization, sexual violence, enforced disappearance and the crime of apartheid. This statute rejects the requirements of the presence of armed conflict and discriminatory grounds that are enshrined under the ICTY and ICTR respectively.

As Bassiouni contends, based on the above statutes one can generally understand that, crime against humanity is one of the crimes that attains the level of jus cogens that constitute an erga omnes duties which is non-derogable. These duties are duty to prosecute, the non-applicability of statutes of limitation, immunities, superior order (save as mitigation of sentence), the universal application of these obligations by all states of the world whether in times of peace or war and the universal jurisdiction over the perpetrators of this crime (Bassiouni, 1997). Additionally, these instruments, according to Cassese show that crime against humanity is derived from those dominant human right laws like the rights to life, not to be tortured, to liberty and security of the person and the like which are enshrined in different international human right instruments like the Universal Declaration of Human Rights, the European Convention on Human Rights, the UN Covenant on Civil and Political Rights and others (Cassese, 2003).

\section{Crime against Humanity under the Ethiopian Legal Framework: How Far It Is Incorporated?}

As explicated above, crime against humanity is among the jus cogens crimes that entails erga omnes duties on the international community. Therefore, undoubtedly, the Ethiopian government has a duty to prosecute the perpetrators of the crime. Such erga omens duties of the government are emanated either from International conventions to which Ethiopia is a party or the customary international laws which have universal application.

With regard to treaties, it is also quite understandable from the cumulative 
reading of article $9(4)^{2}$ and $13(2)^{3}$ of the FDRE constitution those treaties which are already adopted as parts of the law of the land in which the government has a duty to prosecute upon the violation of such treaties. In fact, regarding the human rights treaties some scholars and government officials claim that they have no clear provision that obliged member states to prosecute those who violate human rights. However, presently, the international community has reached on consensus that the authoritative interpretation of such treaties affirmed that a state parties are duty bound to investigate, prosecute and punish those who are responsible for serious violations of human rights that obviously include crime against humanity. Thus, since Ethiopia is a member state to various human right treaties, it has erga omens duty to prosecute the perpetrators of such crime including crime against humanity.

On the other hand, customary international law is other source that obliged the Ethiopian government to prosecute those who commit crime against humanity as it has universal application in various jurisdictions.

As expounded elsewhere above, the establishment of different international tribunals in Rwanda, Yugoslavia, sera Leon and also International criminal court (ICC) demonstrated that the prosecution of core international crimes including crime against humanity is served as customary international laws (Bassiouni, 1997). Thus, Ethiopia like any states across the world has a duty to respect these customary international laws and thus adopt its legal systems in a way that would enable to fight against impunity particularly with regard to Crime against humanity. In other words, the failure of Ethiopia to investigate, prosecute and punish repeated or notorious violations of jus cogens norms, breaches the customary obligations to respect the same set of peremptory rights.

Therefore, the next part attempts to gauge the position of the Ethiopian laws in terms of incorporating crime against humanity in its different parts with a view to prosecute those who commit crime against humanity at any rate. As such it will try to explore the possibility or other wise of fighting impunity for crime against humanity in Ethiopia. Hence, the extent how crime against humanity is incorporated under the 1957 Ethiopian penal law, the FDRE constitution and the FDRE criminal law are particularly evaluated here under respectively.

\subsection{The 1957 Penal Code}

This is the first codified penal law in the history of Ethiopia. The drafters of this law tried to incorporate a wide range of crimes with their respective punishments. This law stipulated crime against humanity under article 281 . The full content of this provision is provided as follows.

\footnotetext{
${ }^{2}$ As per this specific sub article "All international agreements ratified by Ethiopia are an integral part of the law of the land".

${ }^{3}$ This sub article portrays that "The fundamental rights and freedoms specified in this Chapter shall be interpreted in a manner conforming to the principles of the Universal Declaration of Human Rights, International Covenants on Human Rights and International instruments adopted by Ethiopia".
} 
Art. 281. Genocide; Crimes against Humanity

Whosoever, with intent to destroy, in whole or in part, a national, ethnic, racial, religious or political group, organizes, orders or engages in, be it in time of war or in time of peace:

1) killing, bodily harm or serious injury to the physical or mental health of members of the group, in any way whatsoever; or

2) measures to prevent the propagation or continued survival of its members or their progeny; or

3) the compulsory movement or dispersion of peoples or children, or their placing under living conditions calculated to result in their death or disappearance, is punishable with rigorous imprisonment from five years to life, or, in cases of exceptional gravity, with death (The Penal Code of Ethiopia, 1957).

From this particular provision, one can deduct diverse essential things. This law, similar with article 3 of the genocide convention, make punishable not only completed crimes, but also inchoate crimes like organizing, ordering or engaging. On the other hand, as vividly revealed on the same provision, Crime against humanity is not stipulated in a separate provision. Rather, looking into the constitutive elements of the same article, like the defendants of the Derg officials argued the penal law blends crime against humanity with genocide (Tiba, 2011). Thus, it is pretty possible to contend that the definition given for crime against humanity in this specific law is more blended to the definition of genocide as stipulated under article 2 of the genocide convention since it requires special intent to destroy in whole or in part a national, ethnical, racial or religious group (Convention on the Prevention and Punishment of the Crime of Genocide, 1948).

Nonetheless, the penal code is also different from the genocide convention for two basic reasons. The first one is the fact that it gives a particular protection "political groups". The defendants in Special Prosecutor v. Colonel Mengistu Haile-Mariam et al., argued that the inclusion of "political groups" as protected groups against the crime of genocide under article 281 of the 1957 Penal Code is incompatible with international law (Bassiouni, 2011). Put differently, it went beyond what was and is still customarily provided in genocide-related provisions in international treaties and various domestic laws.

However, the Federal high court has rejected their claim. As per the argument of the court;

Article 281 of the Ethiopian Penal Code, which was enacted to give a wider human rights protection, should not be viewed as if it is in contradiction with the Genocide Convention. As long as Ethiopia does not enact a law that minimizes the protection of rights afforded by the Convention, the mere fact that Ethiopia is a party to the convention does not prohibit the government from enacting a law, which provides a wider range of protection than the Convention. Usually international instruments provide only minimum standards and it is the duty of the Ethiopian Government to enact laws that assist their implementation (Debebe, 2003). 
Taking in to account the above arguments, it is hardly possible to say that crime against humanity is manifestly criminalized under the penal code of Ethiopia. According to some of these proponents and also as witnessed in the prosecution of Derg officials, nothing has been expressed about crime against humanity in this particular provision, except the inclusion of crime against humanity as a caption with the crime of genocide as "Genocide; Crime against humanity". According to Debebe;

If the intention of the legislature were also to penalize crimes against humanity, the wordings of the title would appear as "Genocide and Crimes against Humanity". The separation of the two words without any conjunction but by semicolon is rather an indication that the offence is one, which is genocide, and the phrase "Crimes against Humanity" was used as explanatory to the crime of genocide (Debebe, 2003).

The second peculiar feature of the penal code that distinguishes it from the genocide convention is the fact that the prior law includes "peoples" under the act of forcible transfer. It is simply because of the reason that, under article 2(e) of the Genocide convention, it is only children that are protected from forcible transfer (Debebe, 2003).

The reason for such unclear criminalization of crime against humanity in such a way is far from clarity. However, most scholars agreed that this may be emanated either from two essential reasons. Either from the deliberate deeds of the drafters or the absence of specialized International Convention that Ethiopia could learn from during that epoch (Bassiouni, 2011).

Conversely, others like the special prosecutor at the prosecution of the Derg officials argue that, Ethiopian law has long recognized a duty to prosecute crimes against humanity by, for example, the incorporation of "Offenses Against the Law of Nations" in Article 281 and following of the Penal Code of 1957 (Bassiouni, 2011). Similarly, it was revealed that the Ethiopian Penal Code at the time was progressive in its inclusion of the prevailing international criminal law and international humanitarian law standards in the absence of well-established international jurisprudence at the time of its enactment though it has its own limitations in terms of giving the proper definition for crimes against humanity (Debebe, 2003).

This writer is the enthusiast with the first argument. It is grim to ponder that crime against humanity is clearly stipulated under this law. As said above, it is glowing to argue that this specific law had better enunciated the elements of genocide than crime against humanity. This writer also doesn't believe that Bassiouni has made critical appraisal when he uttered as if Ethiopia had properly criminalized crime against humanity notwithstanding his prominence in the field of international criminal law (Bassiouni, 2011).

Because of lack of certainty, it is difficult to understand the very nature and penalty of crime against humanity in this specific law. Thus, even prosecuting 
perpetrators of crime against humanity as per 281 would violate the principle of legality. This is because of the fact that, the notion of legality requires that a certain law shall be clearly written including its penalties. In addition, it must also be announced to the public with a view to know the consequence of their actions. Put in a wider perspective, "Legality first ensures that one who wishes to avoid criminal liability may do so by providing notice of what acts the state or other law making and law enforcement entity will consider criminal and what the available penalties will be. It promotes predictability in judging the legal consequences of one's actions" (Gallant, 2009). Hence, it is plausible to conclude that prosecuting of those who were alleged by crime against humanity was against core criminal principle of legality. In criminal law, the contradiction to the principle of legality usually has different implications. The first one is the opportunity to the real offenders to escape from criminal liability by using those vague terms and contents. Secondly, it may also serve for the violation of human rights of the accused as those vague and uncertain terms may be unfairly exploited by the government (Wald, 2007).

\subsection{The FDRE Constitution}

This constitution came in to force in 1991. This is the fourth constitution in the Ethiopian constitutional development history next to the 1931, 1955 and 1987 constitutions. This particular law enshrined crime against humanity under article 28. According to sub article 1 of this specific article crime against humanity is stipulated as:

Criminal liability of persons who commit crimes against humanity, so defined by international agreements ratified by Ethiopia and by other laws of Ethiopia, such as genocide, summary executions, forcible disappearances or torture shall not be barred by statute of limitation. Such offences may not be commuted by amnesty or pardon of the legislature or any other state organ (Constitution of Federal Democratic Republic of Ethiopia, FDRE, 1995).

From this provision it is quite possible to infer a couple of important things. The first one is the non-applicability of statute of limitation to this particular crime. The stand of the FDRE constitution in this regard, is complied with the international jurisprudence as the non-applicability of the statute of limitation in case of crimes against humanity at the national level is rules of the customary international law. Convention of torture has also a similar stand as to the non-applicability of statutes of limitation with the ICTY trial chamber in that torture has got a jus cogens status that requires the international community either to prosecute criminals.

Secondly, the legislatures of Ethiopia and any state organ have no any authority to grant amnesty or pardon for those who commit crime against humanity. In a similar fashion, amnesty for those who violate core international crimes should not be granted under the constitution. Put differently, to pass and apply amnesty laws to alleged authors of any such crime would run to counter to that 
treaty obligations (Cassese, 2003). Thus, prohibition of amnesty for those crimes is becoming the customary international law. In this regard, it is virtuous to mention the argument of the UN special representatives. At the Peace agreement between the government of Sierra Leone and the Revolutionary United Front of Sierra Leone the representative affirmed that not only amnesty but also pardon shall not apply to International crimes of genocide, crimes against humanity, war crimes, and other serious violations of international humanitarian law (Cassese, 2003).

Accordingly, it is bluntly portrayed under the constitution that the Ethiopian government has shown a commitment to prosecute the perpetrators of those universally monstrous crimes by prohibiting pardon, amnesty and rejecting any statute of limitation and thereby it discharges its treaty obligations (Alemayhu, 2010). In other words, the Ethiopian government has recognized the duty to prosecute crimes against humanity in its constitution for not only it causes mass violation of human rights but also it entrenched on customary international law (Alemayhu, 2010).

However, at this juncture it is also imperative to mention the way that the FDRE constitution has stipulated crime against humanity is a bit different from what is enshrined under the international jurisprudence. Because, the constitution put crime against humanity as it includes genocide, torture, forcible disappearances, and summary execution under the caption of the same provision as if it is the collection of them. Though it is rarely possible to argue that such stated crimes in the constitution could not be blended with crime against humanity in one or another way, particularly with torture or forcible disappearances, putting these crimes as the constituents of crime against humanity is wrong as far as they are naturally different crimes. Thus, it would have been better to provide crime against humanity as a separate crime in accordance with the international jurisprudences.

The other fascinating thing worth mentioning here is the inclusion of the phrase like "defined international agreements ratified by Ethiopia and by other laws of Ethiopia ..." under this particular provision. This is because of the reason that, there was no a separate international treaty regarding crime against humanity at the time of the adoption of the constitution. The only well-developed International treaty is the so-called Rome statute. Even this statute is come into existence after the coming in to force of the FDRE constitution provided that Ethiopia doesn't yet ratify the treaty. Plus, it is pretty clear that there was no Ethiopian legal framework that governs crime against humanity during the promulgation of the constitution except the former penal code with its limitations as provided above.

\subsection{The FDRE Criminal Code}

The current Ethiopian criminal Code was come in to force on July 9, 2005 by replacing the 1957 penal code. As vividly revealed in its preface, there are a couple 
of crucial reasons for the coming in to existence of the given law. Among others, under the preface it says, “...on the regional and international levels due to, the grave crises they are causing, the Penal code does not adequately deal with crimes with the degree of seriousness they deserve" (Criminal Code of Federal Democratic Republic of Ethiopia, 2004). From this phrase it is quite fathomable that the former penal code was not as effective as it was expected in adequately dealing with serious crimes like crime against humanity. Thus, based on the preface it is pretty healthy to envision that FDRE criminal code should have a better stand than the former penal code in terms of addressing those internationally recognized heinous crimes in general and crime against humanity in particular including their definition, constitutive elements and penalties.

Nonetheless, paradoxically, this law has failed at least to give recognition specifically to crime against humanity. The position of the law in this regard, is astonishing at least for the following four fundamental reasons. The first reason is the failure of the law to be complied with its objective which is provided under its preface. As said above, the chief objective for the coming in to existence for this criminal code is the weakness of the 1957 penal code in properly addressing serious crimes like crime against humanity. Accordingly, it is fair to expect the code to come up with better provisions in criminalizing crime against humanity. However, what happened was against the main purpose of the revision of the 1957 penal code and the coming in to existence of this code itself. In other words, the objective of revising the 1957 penal code to have a better framework regarding international crimes including crime against humanity is failed and also contradictory with what is uttered in the preface of the current criminal code.

The second reason is about issue of the availability of international jurisprudence. Relatively the presence of well-founded international jurisprudences which ranged from London charter to Rome statute regarding the recognition of crime against humanity were existed during the enactment of the current criminal code than at the time of the enactment of the former penal code from which the Ethiopian legislature could share various significant things regarding the criminalization of the crime against humanity in this specific code.

Thirdly, at the time of the adoption of FDRE criminal code and of course currently, the Ethiopian government is claiming to be most committed for the protection, promotion and respect human rights than what was in 1950's. Accordingly, it becomes a party to different crucial international human right treaties. This implies that upon the violation of such fundamental human rights, it has a vow to prosecute those who violate such fundamental human rights and punish those who are proved to be guilty. From this line of argument one can claim that the Ethiopian government has recognized its erga omnes duties to prosecute the perpetrators of crime against humanity which is one of the causes for the violation of human rights. In this regard, though the Ethiopian government has been expected to have better legal frameworks particularly the criminal code, with a 
view to accomplish its international duties, it failed to do so.

The fourth reason is related with the capacity of draftsmen. It is possible to argue that the capacity of the criminal law drafters in having exposure and knowledge regarding crime against humanity has been relatively increased as the international jurisprudence also become advanced and well developed about core crimes like crime against humanity.

Cognizant of the failure of the law to give incorporate crime against humanity, it would be fair to ask a question that why the Ethiopian government remorse to explicitly criminalize crime against humanity in FDRE criminal code different from other various international statues? In this respect, it is hard to exactly know the intention of the Ethiopian legislature. However, for this writer, by taking different international and national scenarios, it is conceivable to put some possible reasons as follows.

The first reason is linked with lack of an independent convention. Though it is contended elsewhere above that the international jurisprudence became developed during the adoption of this code, yet it is hardly possible to heart fully argue that there was a separate convention as to crime against humanity. In other words, there was still lack of historical clarity and absence of independent convention about crime against humanity unlike genocide, torture and other heinous crimes. According to Bassiouni, "The general ambiguity of states towards crime against humanity is best evidenced by the fact that, to date, no specialized international convention on that crime exists..." (Gallant, 2009). For long time, the international community pronounced crime against humanity by intermingling with either war crime or genocide like our former penal code. Consequently, this writer believes that this lack of specialized convention regarding the crime might be a ground for the Ethiopian government to neglect it.

The second reason is related with the very nature of crime against humanity. As it is explicable from history in various jurisdictions, crime against humanity is usually committed by the state officials themselves through the policy of causing a wide spread attack. In other words, Crime against humanity is directed toward state actors whose conduct is the offspring state policy. Plausibly, states have little interest in criminalizing the conduct of their officials, and certainly their heads of state and other senior officials who could be charged with such a crime. Explicit criminalization of crime against humanity makes the political, military and, police leaders at a risk of prosecution for their crime against humanity actions. From this assertion one may argue that the Ethiopian government might intentionally refrain itself from explicitly criminalizing crime against humanity in the FDRE criminal code with a view to prepare "hiding cave" for its officials. In a wider perspective, though the Ethiopian government seems committed to fighting impunity in the country and stands for the prosecution of the perpetrators of those mass violations of human rights including crime against humanity under article 28 of the constitution, it failed to take the same position again in FDRE criminal code. Rather, as argued above in this law 
it seems that things are made for the impunity of officials themselves rather than showing its international responsibility of prosecuting such perpetrators of crime against humanity which are stemmed from different treaties to which Ethiopia is a party and also customary international law. If the Ethiopian government has a political will to take reasonable steps regarding the prosecution and extradition of perpetrators of crime against humanity, it might incorporate this crime under title II of the code that specifically stipulated crimes in violation of international law.

\section{Is It Really Possible to Fight against Impunity by Using the Current Ethiopian Legal Framework?}

The evaluation of the extent to which crime against humanity is incorporated under the above three Ethiopian legal instruments provokes us to raise one essential question. Whether is it quite possible to prosecute the perpetrators of crime against humanity thereby to fight against impunity concerning crime against humanity with the current stand of Ethiopian legal regime?

In an attempt to answer the above essential question, scholars have different views. Some scholars argue that, those who commit crime against humanity can be either prosecuted in the current stand of the Ethiopian legal framework though not in absolute way. For these scholars, the possibility is emanated not because of the fact that crime against humanity is clearly provided under the Ethiopian legal framework, rather it is because of the reason that this crime in not less situations basically blend with crimes like war crimes and genocide which are criminalized under part II title II of the special part of the FDRE criminal code. This is because, as far as crime against humanity is broad, crimes like genocide and war crime may be crime against humanity at the same time.

There are authors who put genocide as sub-set of crime against humanity. For instance, in the case between prosecutors V. Kayishema case the Trial chamber of ICTR held that;

The definition of the crime of genocide was based upon that of crimes against humanity, that is, a combination of "extermination and persecutions on political, racial or religious grounds" and it was intended to cover "the intentional destruction of groups in whole or in substantial part" (emphasis added). The crime of genocide is a type of crime against humanity

(Cassese, 2003).

Similarly, Peter argued that "International law recognizes genocide as one of the crimes against humanity. Therefore, it is a common practice to view the act of genocide as an act of crimes against humanity" (Debebe, 2003). In such situations the perpetrators of crime against humanity can be prosecuted in Ethiopian in the name of crimes provided under part II title II of the code that regulated crimes in violation of international law.

However, this argument has different limitations. There are numerous cir- 
cumstances where crime against humanity doesn't blend with other crimes provided above. Thus, though crime against humanity is explicitly enshrined under the FDRE constitution which is supreme law of the land, it is grim for the government to effectively fight against impunity as far as there is absence of separated and specific provision in the current criminal law that stipulates the criminalization of crime against humanity including its penalties.

Therefore, prosecuting the perpetrators of crime against humanity in the current stand of Ethiopian legal regime, would amount to the violation of the principle of legality. Based on the notion of legality, to punish a certain act, the act must be clearly prohibited as well as its punishments must also be clearly provided in the text of the law at the time it was committed (Debebe, 2003). As far as the main purpose of criminal law is giving faire notice about crimes and punishments the law must be written in clear and certain manner that causes no ambiguity to the public. In other words, nothing is a crime and that no punishment may be imposed except by previously proclaimed status (Debebe, 2003). However, the Ethiopian legal regime failed to give specific definition and penalties of crime against humanity as far as provisions are fragmented in different parts of the law and not clearly stipulated in a way that every individual can learn and refrain himself from committing such crime on the other side. Therefore, it is healthy to assert that this specific law is unsuccessful with regard to achieving its deterrence (both special and general) as well as the objective of maintaining peace and safety of the people provided under the preamble of the criminal law. Similarly, it is not quite easy for the government to respect its "duties to prevent atrocities prohibited by international criminal law and duty to bring alleged perpetrators to trial" (Debebe, 2003). Subsequently, prosecuting the perpetrators of crime against humanity by the current Ethiopian legal framework so as to fight against impunity contravenes the principle of legality.

This vividly reveals that there is a legal lacuna in Ethiopian legal framework to effectively prosecute the perpetrators of crime against humanity and therefore to effectively fight against impunity. When legal lacuna occurs, Ethiopian courts are duty bound to search certain way outs. As stated elsewhere above, obviously, the best way out to make liable the perpetrators of crime against humanity in Ethiopia is applying customary norms as far as the failure of domestic legal frameworks to incorporate certain matters like crime against humanity is among the reasons for the applicability of customary international law in domestic arena.

Custom to serve as a law certain important parameters must be fulfilled. It has to be long standing, widespread and practiced in a uniform and consistent way among nations. In other words, in order for a standard to become customary international law, it must be one adopted in writing or in practice by most or all civilized nations. States need not, however, be universally effective in implementation of the principle. Also, states must adhere to the practice because they feel there is a legal obligation. 
Therefore, as provided above, the prosecution of international crimes in general, crime against humanity in particular is considered to be jus cogens norm that springs erga omnes obligations to the international community which is not-derogable in any scenario. According to Cherif Bassiouni;

International crimes that rise to the level of jus cogens constitute obligation erga omnes which are inderogable. Legal obligations which arise from the higher status of such crimes include the duty to prosecute, the non-applicability of statutes of limitations for such crimes, the non-applicability of any immunities up to and including heads of state, the non-applicability of the defense of "obedience to superior orders" (save as mitigation of sentence), the universal application of these obligations whether in time of peace or war, their non-derogation under "states of emergency", and universal jurisdiction over perpetrators of such crimes (Bassiouni, 1997).

These jus cogens norms are the top forms of customary international laws and therefore they are applicable in Ethiopia. However, the Ethiopian legal framework is silent regarding the domestication and applicability of customary international law unlike the domestication of treaty laws that are explicitly cherished under article 9(4) and 55(12) $)^{4}$ of the FDRE constitution.

Though Putting custom as a source of Ethiopian laws by itself doesn't indicate as customary international laws are properly domesticated under Ethiopian laws, both article 9(4) of the constitution and also 2(2) of Federal Courts (Amendment) Proclamation No. 321/2003 stipulated custom as the source of Ethiopian laws. Therefore, in Ethiopia, without proper domestication of customary international laws, the prosecution of the perpetrators of crime against humanity based on these provisions my cause various controversies because of the following reasons.

The first reason is concerning the nature of customary international laws. Yet, knowing and clearly identifying the exact nature of customary international laws is unsettled problematic issue. It is good to see what Kathleen M. Kedian argued about the challenge of practicing customary international law in the US courts as far as his argument is similarly applicable for Ethiopian courts too.

He said,

The ambiguities inherent in defining and using customary international law have sparked heated debates regarding its use, particularly in international human rights claims in domestic courts. On one side of the debate are those who maintain that U.S. courts have a responsibility to enforce and uphold international law, and should continue to do so even when deciding a claim requires the courts to make difficult customary international law findings. On the other side are critics who argue that the ambiguities of customary international law are too great, that U.S. courts lack the authority to "find"

${ }^{4}$ It stipulated that "The House of Peoples' Representatives shall ratify international agreements concluded by the Executive". 
customary international law, and that letting them do so offends federalism and separation of powers principles (Kedian, 1999).

Accordingly, customary international law has no base to be enforceable in Ethiopia without explicit recognition and domestication. Accordingly, prosecuting those who committed crime against humanity is controversial without the clear domestication and recognition of customary international law in Ethiopia.

The other problematic issue is related with the nature of crime against humanity itself. As it is observable form different international legal regimes, among the core international crimes, it is crime against humanity whose nature is not provided in a clear and certain manner. Therefore, lack of clear scope of crime against humanity and the absence of domestic laws that clearly stipulated crime against humanity coupled with the limitation of customary international law leads us to conclude that the application of customary international law in Ethiopia may jeopardize the objective of securing peace and security provided under the criminal code.

Lastly, applying customary international law in such a way may also be very tough when we see in line with the caseloads that the Ethiopian courts are suffering from. This doesn't definitely give an opportunity to refer and make critical analysis on international norms. Even the judges have such sufficient time to refer these international laws, in most of the cases they have no a necessary competence to give a critical analysis and comparison of international norms in line with the Ethiopian laws.

\section{Concluding Remarks}

Crime against humanity is one of the core international crimes. It was formally introduced to the international law during the Nuremberg trail of Nazi immediately after the horrific incidence of the WW II. Then, its definition and concept get developed in the international jurisprudence. International tribunals particularly ICTY and ICTR were the crucial ones. However, better definition and the most acceptable definition has been given by the Rome statutes.

As repeatedly said above states have an erga omnes duty to prosecute the perpetrators of international crimes in general and crime against humanity in particular. Hence, with no shadow of doubt, Ethiopia has such duty to prosecute crime against humanity which is emanated either from different treaties to which Ethiopia is a party or from customary international laws. To that end, Ethiopia should have different legal and institutional frameworks with respect to crime against humanity. To know the extent of how far crime against humanity incorporated under the Ethiopian legal framework, the writer has tried to assess the 1957 penal code, the FDRE constitution and the FDRE criminal code.

The 1957 penal code is the first modern criminal code in Ethiopian legal history which criminalizes crime against humanity under article 281. However, there are divergent arguments in this regard. Some consider that this code does not clearly stipulate crime against humanity except putting the term as a caption 
as "Genocide; Crime against humanity". According to this line of argument, article 281 of this code rather contains the definition of genocide as enshrined under article 2 of the genocide convention with the exception of giving a protection to political groups. Conversely others argue that, though this code lacks some clarity, it had a breakthrough in recognizing crime against humanity firstly in Ethiopia. Therefore, based on this argument, Ethiopia has a good stand in prosecuting crime against humanity long before half a century. It is possible to understand from this particular article as the crucial mental element required intention since this article is more blended to the definition of genocide. Similarly, inchoate crimes like organizing and ordering are punishable.

Crime against humanity is also enshrined under article 28 of the FDRE constitution. Ethiopia has revealed more pledge in realizing its erga omnes duty fighting against impunity regarding crime against humanity even by totally prohibiting statutes of limitation, amnesty and pardon to the perpetrators of crime against humanity in the constitution. This makes the constitution complied with the international jurisprudence. However, this provision encompassed distinct crimes like genocide under the caption of crime against humanity while these crimes are separate and distinct crimes in different International Statutes including the Rome statute. This manifests that though we observe the term crime against humanity under the provision, as part of the Ethiopian legal framework, it is hard to argue that there is not that much development in fighting against impunity particularly the issue of crime against humanity.

Surprisingly, though the current criminal code was adopted almost after half a century and a decade from the adoption of 1957 penal code and the FDRE constitution respectively, it totally neglects to embrace crime against humanity. It is surprising for the following four reasons. The first one is that the law is self deafting. When we closely observe the preamble of the law one of the fundamental reasons for the coming into existence of this law is the weakness of the 1957 penal code in properly addressing serious crimes like crime against humanity. However, the law let alone it brought new developments about crime against humanity it totally failed to give at least some recognition. The other thing which surprises us in relation to this law is the status of the international jurisprudence. When this law was adopted the international jurisprudence was more developed when we compared with the time when the 1957 penal law and the FDRE constitution were enacted.

The other reasons are the promise and commitment of the government in fighting against core crimes in general and crime against humanity in particular. But sadly, as it is provided above this law to tally rejected to give recognition to crime against humanity.

The fourth reason is related with the capacity of draftsmen. It is possible to argue that the capacity of the criminal law drafters in having exposure and knowledge regarding crime against humanity has been relatively increased as the international jurisprudence also become advanced and well developed about 
core crimes like crime against humanity.

In nutshell, this was against the expectation of scholars, the Ethiopian people and the international community as it was expected to come up with better enhancements regarding the criminalization of crime against humanity.

The place of crime against humanity under the Ethiopian legal framework provokes us to raise one important question that is the possibility o fighting impunity particularly in relation to crime against humanity. Form the above assessment we conclude that there is a legal lacuna for prosecuting those who found guilty of crime against humanity. Though when this type of challenge happens using customary international law is an option due to the nature of crime against humanity itself, customary international laws, and the problem of domestication of customary laws has put a challenge to effectively fight against humanity in Ethiopia. Even Ethiopia opts to prosecute crime against humanity by searching some options as those law stands would cause various problems. For the first thing it may serve for the government to use its power arbitrarily. For the second it may cause for the violation of the fundamental principle of criminal law which is known as the principle of legality. Lastly, it also serves as tool for the violation of fundamental human rights of individuals who might be alleged for committing crime against humanity.

Thus, this writer recommends the Ethiopian government to amend both FDRE constitution and criminal code and thus stipulate crime against humanity explicitly in a special provision like genocide, war crime in line with the international statutes so that it can discharge its erga omnes duties.

\section{Conflicts of Interest}

The author declares no conflicts of interest regarding the publication of this paper.

\section{References}

(1948). Convention on the Prevention and Punishment of the Crime of Genocide.

(2011). Handbook on International Criminal Law. https://www.e-elgar.com/shop/research-handbook-on-international-criminal-law?web site $=$ uk_warehouse

Alemayhu, F. (2010). Prosecution of Crimes against Humanity and Genocide in Africa: A Comparative Analysis. LLM Thesis, Addis Ababa: Addis Ababa University.

Bassiouni, M. C. (1997). International Crimes: Jus Cogens and Obligatio Erga Omnes. Law and Contemporary Problems, 59, 63-70. https://doi.org/10.2307/1192190

Bassiouni, M. C. (2011). Crimes against Humanity: Historical Evolution and Contemporary Application (pp. 1-9). Cambridge: Cambridge University Press.

Cassese, A. (2003). International Criminal Law. Oxford: Oxford University Press.

Cerone, J., \& Couto, S. S. (2004). International Criminal Law: A Discussion Guide (pp. 11-14). Washington DC: Washington College of Law.

Constitution of Federal Democratic Republic of Ethiopia, FDRE (1995). Federal Democratic Republic of Ethiopia. Proclamation No. 1/1995 Proclamation of the Constitution 
of the Federal Democratic Republic of Ethiopia, Addis Ababa.

Criminal Code of Federal Democratic Republic of Ethiopia, FDRE (2004). Federal Democratic Republic of Ethiopia, Proclamation No. 414/2004 Proclamation of the Criminal Code of the Federal Democratic Republic of Ethiopia, Addis Ababa.

Cryer, R., Friman, H., Robinson, D., \& Frontmatter, E. W. (2007). An Introduction to International Criminal and Procedure (pp. 187-189). Cambridge: Cambridge University Press. https://doi.org/10.1017/CBO9780511801006

Debebe, H. (2003). Prosecution of Genocide at International and National Courts. LLM Thesis, Kampala: Makerere University.

Gallant, K. S. (2009). The Principle of Legality in International and Comparative Criminal Law (pp. 20-23). Cambridge: Cambridge University Press. https://doi.org/10.1017/CBO9780511551826

Human Rights Watch (2005). Ethiopia Reckoning under the Law. https://www.hrw.org/report/1994/12/01/ethiopia-reckoning-under-law

Kedian, K. M. (1999). Customary International Law and International Human Rights Litigation in United States Courts: Revitalizing the Legacy of the Paquete Habana. William \& Mary Law Review, 40, 1395.

Rome Statute of the International Criminal Court (2002). http://legal.un.org/icc/statute/99_corr/cstatute.htm

The Penal Code of Ethiopia (1957). Conquering the Lion of the Tribe of Judah, No. 158/1957, Addis Ababa.

Tiba, F. K. (2011). The Trial of Mengistu and Other Derge Members for Genocide, Torture and Summary Executions in Ethiopia. http://ssrn.com/abstract=2635348

Wald, P. M. (2007). Genocide and Crime against Humanity. Washington University Global Studies Law Review, 6, 626-630. 